\title{
Soğuk Savaş Sonrası Dönemde ABD-BM ilişkisi
}

\author{
Tamer KAŞIKÇI*
}

Soğuk Savaş Sonrası Dönemde ABD-BM ilişkisi

Özet

Bu çalışmanın temel amacl, çağdaş uluslararası sistemde en büyük uluslararası örgüt olan Birleşmiş Milletler (BM) ile yine sistem içerisindeki en önemli güç olarak tanımlanan $A B D$ arasındaki ilişkiyi analiz etmektir. Uluslararası iliş̧kiler literatüründe devlet/uluslararası örgüt ilişkisini inceleyen geleneksel yaklaşımlar örgütleri devletlerin güç yada çıkarını maksimize eden araçlar olarak tanımlamaktadır. Bu çalışmada ana akım yaklaşımların söz konusu iki aktör arasında kurdukları tek taraflı ilişki eleştirilerek genelde devlet ve örgüt özelde ise $A B D$ ile $B M$ arasında karşılıklı bir ilişki olduğu iddiası tartışılmaktadır. ABD açısından varlığını ve operasyonlarını sürdürmek için ABD'ye muhtaç olan BM, bu ülkenin hegemonyasını yaymasında önemli bir araçtır. Diğer yandan ise, BM, merkezinde yer aldığı uluslararası sistemin normatif yapısı vasıtasıyla uluslararası sistem içerisindeki tüm aktörlerin yanı sıra ABD dış politikası üzerinde de sınırlayıcı bir etkiye sahiptir.

Anahtar Kelimeler: ABD Dış Politikası, Birleşmiş Milletler, Uluslararası Örgüt, Çok Taraflıık, Normatif Yapı.
The Relationship between the US and the UN in the Post-Cold War Era

\section{Abstract}

The main objective of this study is to analyze the relationship between the United Nations which is the major international organization in the international system and the United States which is defined as the only super-power in the system. Regarding the relation between state and international organizations the conventional approaches argue that organizations are the tools for the states to maximize their power or interest. By criticizing the conventional approach which defines a unilateral relation between these two actors, the study is arguing that there is a mutual relation between state and international organization in general, and between the US and the UN in particular.From the US perspective, the UN which needs the US' power in order to continue its existence and execute its operations is a fundamental tool in the expansion of its hegemony. On the other hand the UN which is the central actor of the normative dimension of the international structure has the ability to limit the US' foreign policy.

Key Words: The US Foreign Policy, the United Nations, International Organization, Multilateralism, Normative Structure

\section{Giriş}

1945 yılında kurulduğunda BM, iki büyük savaşın ardından uluslararası barışı temin edecek ve kurumsallaştıracak bir aktör olarak tasarlanmıştır. Geçen zaman içerisinde BM'nin bu misyonu ne derecede gerçekleştirebildiği, uluslararası ilişkiler literatüründe üzerinde halen uzlaşının olmadığı

\footnotetext{
*Tamer KAŞıKÇI, Dr.Öğr.Üyesi., Eskişehir Osmangazi Üniversitesi, Uluslararası İlişkiler Bölümü, tamer kasikci@gmail.com; ORCID ID orcid.org / 0000-0003-2299-8863
} 
bir sorun alanı olarak varlığını sürdürmektedir. Bununla birlikte bugün BM'nin uluslararası aktörler arası ilişkiler içerisinde "tartışmalı" da olsa bir yeri olduğunu göz ardı etmek mümkün değildir. Her yıl toplanan Genel Kurul, uluslararası sistemde var olan güncel tartışmaların tüm aktörler tarafından ele alındığı bir zemin oluştururken, Güvenlik Konseyi kararları da sistem içerisindeki tüm aktörlerin ilgili alandaki davranışlarını şekillendirmede önemli bir rol oynamaktadır. Buna benzer yönleri ile BM, uluslararası ilişkilerin düzenlenmesinde önemli bir aktör olarak sistem içerisinde varlığını sürdürmektedir.

Böylesi önemi olan bir aktörün, sistem içerisindeki başat güç konumunda olan ABD ile ilişkileri de açıklanması gereken önemli bir husustur. ABD gibi hegemon olarak tanımlanan bir gücün genel olarak uluslararası örgütlerle, özelde ise Birleşmiş Milletler ile olan ilişkisi değerlendirildiğinde Uluslararası Iliş̧iler disiplinindeki genel kanı, BM'nin ABD'nin hegemonyasını yaygınlaştırma araçlarından bir tanesi olduğudur (Puchala, 2005, s.572-573). Aşağıda da değinileceği üzere, kurulduğu günden bu yana $A B D$ 'nin $B M$ ile ilişkileri değerlendirildiğinde, $B M$ 'nin önemli uluslararası sorunlar karşısındaki tavrı ABD ile paralellikler içermekte, ABD'nin karşı olduğu durumlarda BM'nin genel olarak etkisiz kaldığı görülmektedir.

Ancak bu bütüncül yaklaşım ABD-BM ilişkisini yüzeysel ve tek yönlü bir bağlamda açıklamakta, BM'nin ABD dış politikası üzerindeki olası etkilerini göz ardı etmektedir. Bu nedenle BM gibi uluslararası sistemin temel aktörlerinden birisi haline gelmiş bir örgütün, yine sistemin en önemli aktörlerinden bir tanesi olan $A B D$ ile ilişkisini daha kapsayıc bir yaklaşım ile analiz etmek gerekmektedir. Bu bağlamda bu çalışmada $A B D$ ile BM arasındaki ilişkinin karşııılı bir ilişki olduğu varsayımı ileri sürülmüştür. Bu kapsamda bir yandan, ABD’nin hegemonyasını sürdürmek ve uluslararası sistem içerisinde yaygınlaştırmak için BM gibi küresel bir örgüte ihtiyaç duyduğu, buna karşlık BM’nin de örgütün ve operasyonlarının maliyetini karşılamak için $A B D$ gibi askeri ve ekonomik açıdan özel bir statüye sahip bir devlete bağımlı olduğu tartışıımışır. Diğer yandan ise yaygın kanının aksine BM’nin merkezinde yer aldığı uluslararası yapının normatif boyutu aracılı̆̆ıyla ABD dış politikası üzerinde sınırlayıcı bir etkisinin görüldüğü varsayımı savunulmuştur. Bu argümanlar anlaşılır olma kaygısı nedeniyle bir tarih kısıtlaması içerisinde değerlendirilecek ve sadece Soğuk Savaş sonrası dönem ele alınacaktır.

Literatürde bulunan akademik kaynakların yanı sıra söz konusu devletin ve örgütün resmi belgelerinden yararlanacak olan çalışma, öncelikle Soğuk Savaş sonrası dönemde ABD dış politikasının genel hatlarının değerlendirildiği, daha sonra ABD'nin BM operasyonlarına yaptığı maddi katkının analiz edildiği ve son olarak da BM’nin $A B D$ dış politikası üzerindeki normatif etkisinin tartışıldığı üç alt başık altında ele alınmıştır.

\section{Soğuk Savaş Sonrası ABD Dış Politikası}

Soğuk Savaş sonrası dönemde ABD’nin dış politikası iki önemli tartışma temelinde şekillenmiştir. Bunlardan birincisi ABD dış politikasında tarihsel olarak bir öneme sahip olan izolasyonizm/müdahalecilik tartışmasıdır. İkincisi ise dış politika uygulamalarında diğer uluslararası aktör- 
lerle beraber hareket etme üzerine kurulu çok tarafılık, ya da bunun tam aksi kutupta yer alan tek taraflılık sorunudur. Bu bölümde Soğuk Savaş sonrasında görev yapan ABD başkanlarının bu iki tartışma içerisinde dış politikalarını nasıl şekillendirdiği ve bu dış politika tercihlerinin BM ile ilişkilere nasıl yansıdığı değerlendirilecektir.

1988 yılında George H. W. Bush başkan seçildiği zaman, Amerikan dış politikası açısından sakin bir dönem yaşanmaktaydı. SSCB ile ilişkiler görece daha olumlu bir durumdaydı ve 1980'ler boyunca sıcak çatışmaların yaşandığı Afganistan ve Güney Afrika gibi bölgelerde çatışmaların çözümü bağlamında ilerleme kaydedilmişti(Haig 1991, s.34). Buna karşın 1989 yılında Berlin duvarının yıkılışı ve ardından 1991 yılında SSCB'nin beklenmedik bir şekilde dağılması bu sakin dönemin sona ermesine neden olmuştur. Bu dönemde Bush yönetiminin gündeminde Almanya'nın yeniden birleşimi, Somali krizi, Yugoslavya'da yaşanan iç savaş ve Irak'ın Kuveyt'i işgali gibi sorunlar bulunmaktaydı. (Cameron, 2005, s.14-18).

Bu sorunlar bir yanda dururken, Bush yönetiminin asıl büyük problemi Sovyet sonrası dönemde ABD'nin nasıl bir dış politika izleyeceğiydi. "Tek kutuplu an” (Krauthammer, 1990/91, s.23) olarak tanımlanan bu yeni dönemde, Soğuk Savaş'tan ABD ile birlikte liberalizmin de galip olarak çıktığını savunan Francis Fukuyama gibi liberal yazarlar, liberalizmin kendiliğinden dünyaya yayılacağını ve ABD'nin de yeni dünyanın bir anlamda keyfini süreceğini iddia ettiler. Diğer yandan ise tek süper gücün sahip olduğu bu eşsiz avantajı abartanlar, bu gücün ABD'yi yer küre üzerinde “istediği her şeyi yapmaya" muktedir kıldığını dile getirmişler ve ABD’nin yeni dünya düzeninin jandarmalığını yapacağını ileri sürmüşlerdir.

Bush yönetiminin dış politikasına bakıldığında, her ne kadar ABD’nin liberalizmin tüm dünyada tek geçerli siyasi yol olarak görülmesinden hoşnut olsa da, bazı yazarların ileri sürdüğü gibi kendi kıtasına çekilip liberalizmin yayılmasını izlemekten ziyade, elindeki küresel gücü kullanarak yeni dünya düzenini oluşturmada aktif bir rol, adeta dünyanın jandarmalığı görevini, üstlendiği görülmektedir. Daha SSCB resmi olarak dağılmadan ABD, Kuveyt işgali karşısında sessiz kalmamış ve Irak'a karşı oluşturulan koalisyonun başını çekmiştir. (Ostergard2006, s.43). ABD bu müdahaleci tavrını 1990’lar boyunca sürdürerek bir anlamda küresel düzeni sağlama görevini üstlendiğini göstermiştir. (Keskin, 2005, sf 52).

Bu müdahaleci dış politikanın tek taraflı mı yoksa çok taraflı mı yürütüleceği hususu değerlendirildiğinde, Bush yönetiminin Körfez Savaşında olduğu gibi, kriz bölgelerine müdahalede çok taraflı bir yöntem izleme gayreti içerisinde olduğu görülmektedir. (Howard 2010, s.489). Dahası Başkan Bush, Soğuk Savaş sonrası dönemi nitelemek için kullandığı "Yeni Dünya Düzeni (New World Order)" kavramı içerisinde Birleşmiş Milletlere merkezi bir rol biçmekte ve BM'nin bu yeni dönemde Soğuk Savaş ortamının yaratmış olduğu süper güç baskısından kurtularak, kurucularının hayal ettiği gibi uluslararası politikada aktif bir aktör haline gelebileceğini ifade etmekteydi(Bush, 1991). Körfez operasyonunun yanı sıra, Bush yönetimi Mozambik, El Salvador ve Kamboçya gibi ülkelerde BM öncülüğünde barış koruma operasyonlarının oluşturulmasına da katkıda bulunarak çok tarafıı̆ıga verdiği önemi göstermiştir (Howard 2010, s.489). 
Öte yandan, 1992 yılında yapılan başkanlık seçimlerinde, seçim kampanyasını Bush yönetiminin dış politikaya ağırlık verirken iç politikayı ihmal ettiği argümanı üzerine kuran Bill Clinton'ın, başkan seçilmesinin ardından dış politikada daha pasif bir tavır sergileyeceği görüşü hakim olmuştur (Cameron 2005, s.18). Buna karşın şiddeti giderek artan Yugoslav iç savaşı, aniden patlak veren Haiti krizi, Somali'de yaşanan iç çatışmalar, yönetimi devraldığı ilk günden itibaren Clinton'ın aktif bir dış politika izlemesini gerektirmiştir. Bu bağlamda Clinton yönetimi, Bush yönetiminin müdahaleci politikalarını sürdürerek Haiti'ye operasyon yapılmasına izin vermiş, Somali'ye asker göndermiş, Bosna ve Kosova'da askeri operasyonlar düzenlemiştir (Herring 2008, s.927-932).

Dış politika söyleminde liberal değerleri ön plana çıkaran Clinton yönetiminin çok taraflılık hususunda Bush yönetiminden daha duyarlı olduğunu öne süren görüşler olmakla birlikte, bu dönemde Kosova krizinde görüldüğü gibi gerekli görülen durumlarda tek taraflı bir politika izlemekten kaçınılmamıştır (Mastanduno 2008, s.40-41). Dış politikada yaşanan bu değişikliğin temelinde Somali'deki başarısızlıklar önemli bir rol oynamıştır(Howard 2010, s.489). Dahası, Başkan Clinton döneminde yayımlanan ve ABD'nin çok uluslu örgütlere yönelik dış politikasını açıklayan 3 Mayıs 1994 tarihli “Presidential Decision Directive/Nsc-25” isimli belge, ABD’nin dünyanın çeşitli bölgelerinde yapılan insani müdahalelere karşı daha seçici olması gerektiğini vurgulamakta ve ABD'nin çıkarlarının tehlikeye gireceği durumlarda BM nezdinde yapılacak barış operasyonlarına katılım sağlanmayacağını açık bir dille ifade etmektedir (Presenditial Directive Decision/NSC 25 1994, s. 2).

Söz konusu askeri operasyonların yanı sıra dünyanın birçok bölgesindeki çatışmalarda arabulucu rol üstlenmesi, Clinton yönetiminin izlediği dış politikanın stratejik bir odağa sahip olmadığı eleştirisini beraberinde getirmiştir. Bu eleştirilerin gölgesi altında seçilen yeni başkan George W. Bush, Clinton yönetiminin bu dağınık politikasını toparlama adına ABD’nin birçok alandaki desteğine son vermiştir. Bu kapsamda Bush yönetimi ilk günlerinde Ortadoğu barış görüşmelerinde daha fazla aktif rol oynanmayacağını, Balkanlara daha fazla asker gönderilmeyeceğini, Kuzey Kore ile diplomatik müzakerelere devam edilmeyeceğini ve Kyoto anlaşmasından çekileceğini ilan etmiştir (Cameron 2005, s.29). Bush yönetiminin dış politikadaki ABD sorumluluklarını azaltma girişimleri 2001 yılında yaşanan 11 Eylül bombalamalarının ardından sona ermiştir. Bu olaydan sonra ilan edilen Bush doktrini kapsamında terörle mücadele bağlamında önce Afganistan sonra da Irak operasyonları düzenlemiş, $A B D$ yeniden ve bu kez daha güçlü bir şekilde dünyanın birçok bölgesinde müdahaleci bir dış politika izlemeye başlamıştır.

11 Eylül, Bush yönetiminin yeni bir dış politika stratejisi belirlemesine neden olmuştur. Bu yeni strateji içerisinde $A B D$ terörle mücadele kapsamında terörist yapılanmaların yer aldığı ve yerel hükümetler tarafından söz konusu yapılanmaların engellenmediği her yere müdahale edebilecektir (Ikenberry 2002, s.51-52). Bu yeni stratejinin bir diğer önemli boyutu ise, ABD’nin söz konusu müdahaleleri yaparken çok taraflı mı yoksa tek taraflı mı hareket edeceği konusudur. Bu bağlamda Başkan Bush 11 Eylül saldırılarının hemen ardından yaptığı o ünlü konuşmasında tüm dünyaya "ya bizimlesiniz yada bizim karşımızdasınız" diyerek, uluslararası toplumu terörle mücadelede destek olmaya çağırmıştır. Bununla birlikte uluslararası toplumdan destek gelmemesi durumunda 
ABD’nin tek taraflı olarak hareket edeceğini vurgulamıştır. (Transcript of PresidentBush'saddressto a jointsession of Congress on Thursdaynight, 2001). Gerçekten de 2003 ylında kısıtlı sayıda devletin desteği ile yapılan Irak operasyonu ABD’nin tek taraflı dış politikasının sembolü olarak görülmektedir.

Bununla birlikte, bu durum, Bush yönetiminin söz konusu yeni stratejisinin genel olarak çok taraflıı̆̆ı, özel olarak da BM ile olan ilişkileri tamamen rafa kaldırdığı anlamına gelmemektedir. Operasyon yapma konusunda oldukça kararlı oldukları Irak örneğinde dahi Bush yönetimi uluslararası toplumun ve BM'nin desteğini almaya çalışmıştır. Örneğin operasyon öncesinde, dönemin Genel Kurmay Başkanı Colin Powell, Birleşmiş Milletler Güvenlik Konseyi üyelerini ikna etme amacıyla BM'de, daha sonra sahte olduğunu itiraf ettiği sözde kanıtlarla, Irak'ta kitle imha silahları olduğuna dair bir sunum yapmıştır (BBC 2004). Bunun yanı sıra, Bush yönetimi BM bünyesindeki barış koruma operasyonlarına da aktif bir katılım göstermiş, başkanlığının ilk döneminde yaklaşık 35.000 personel bu operasyonlarda görev alırken, ikinci döneminde bu sayı 110.000'e yükselmiştir (Howard 2010, s.497).

Bush yönetiminin terörle savaş kapsamında izlediği bu agresif dış politikanın hem dünya genelinde hem de ABD sınırları içerisinde yaratmış olduğu karşıt tepkiler 2008 başkanlık yarışında "değişim” sloganı ile kampanya yürüten Barack Obama'nın galip gelmesini sağlamıştır. Her ne kadar Obama değişim vaadi ile başkanlığı kazanmış olsa da Amerikan gücünün giderek zayıflaması ve terörle savaş doktrininin artık uluslararası politikada kurumsal bir nitelik kazanması nedeniyle, Bush yönetiminin izlediği dış politikada radikal bir değişim yaratamamıştır (Holland 2014, s.2).Yönetiminin ilk yıllarında özellikle Ortadoğu ülkelerine karşı kullandığı yapıcı dil ve Irak'taki Amerikan kuvvetlerini geri çekmesi, Obama'nın Bush'un müdahaleci politikasını değiştireceğine yönelik yorumlar yapılmasına neden olsa da, Obama yönetimi açık ve topyekün operasyonlar yerine Amerikan özel kuvvetlerinin ve insansız askeri araçların kullanıldığı küçük çaplı operasyonlar ile Afganistan, Pakistan, Yemen, Somali gibi ülkelerde müdahaleler yapmıştır (Aaronson 2014, s.129-131).

Müdahalecilik bağlamında süreklilik olmakla birlikte, Obama'nın ABD’nin dış politikasında yaratmaya çalıştı̆̆ı en büyük değişiklik çok tarafıılık hususundadır. Bush yönetiminin saldırgan politikalarının uluslararası toplum nezdinde ABD imajı üzerinde yaratmış olduğu hasarı tamir etme amacıyla yola çıkan Obama yönetimi, uluslararası sorunlarla mücadelede tüm uluslararası aktörlerle birlikte hareket etme gayreti içerisinde olmuştur (Daalder 2016). BM Genel Kurul'unda yaptığı ilk konuşmasında Obama ABD dahil tüm devletlerin evrensel haklara ve BM'ye saygı duyması gerektiğini dile getirmiştir (Wolfgang 2017). Dahası Bush yönetiminin "şer ekseni” (The Washington Post 2002) içerisinde tanımladığı İran ve Kuzey Kore gibi devletlere karşı Obama yönetimi diplomasiyi ve BM içerisinde hareket etmeyi önceleyen bir dış politika izlemiştir (Wolfgang 2017).

Genel olarak değerlendirildiğinde, Soğuk Savaş sonrası ortaya çıkan yeni dünya düzeninde ABD bir yandan sahip olduğu "tek süpergüç" konumunu korumak, diğer yandan da Soğuk Savaş boyunca savunduğu ve hegemonyasının vazgeçilmez bir parçası olan liberal değerleri (Ikenberry 
Tamer KAŞIKÇI

2000) sistem içerisinde yaymak için müdahaleci bir dış politika izlemiştir. Bu dış politika doğrultusunda $A B D$ yönetimleri pragmatist bir bakış açısıyla gerekli gördüğü durumlarda uluslararası toplumun desteğini alan çok taraflı bir politika izlerken, özellikle hayati çıkarlarının söz konusu olduğu meselelerde tek taraflı davranmaktan kaçınmamıştır.

Bu pragmatik dış politika içerisinde, tüm devletleri bünyesinde barındıran yegane siyasi organ olan BM'nin ayrı bir yeri bulunmaktadır. ABD yönetimleri en tartışmalı operasyon kararlarında dahi BM aracilı̆ıyla tüm devletlerin onayını alma gayreti içerisinde bulunmuştur (Reisman 2000, s.1-2). Bu bağlamda $A B D$ için $B M$, hegemonyasını korumasına ve yaygınlaştırmasına yardımcı olabilecek önemli bir mekanizma olarak görülmüştür (Puchala 2005, s.574-575). BM’nin ABD’nin hegemonyasını yaygınlaştırma bağlamında oynadığı rolün en önemli örneğini demokrasi ve insan hakları söylemi oluşturmaktadır. BM ABD’li yöneticilerin dilinden düşürmediği demokrasi ve insan hakları konularını her platformda desteklemekte, bu değerlerin dünya genelinde yayılması için çaba göstermektedir. Bu kapsamda BM'nin ABD'ye demokrasi ve insan haklarını yaygınlaştırma politikasında yardımcı olduğunu söylemek yerinde olacaktır (Johnstone 2004, s. 826). Ancak dünyanın bir çok bölgesindeki otoriter rejimlerle yakın ilişkileri ve Irak müdahalesi gibi uluslararası hukuku yok sayan politika ve eylemleri göz önüne alındığında, demokrasi ve insan hakları gibi liberal değerlerin ABD dış politikası açısından bir amaçtan ziyade bir araç olduğu ve bu değerleri (ve bunları savunan BM'yi) sahip olduğu hegemonik konumu pekiştirmek ve korumak için kullandığı aşikardır.

\section{BM’nin ABD'ye Bağımlılığı}

Yukarıda analiz edildiği gibi ABD’nin Soğuk Savaş sonrası dönemdeki dış politikasının izolasyonizm/müdahalecilik ve tek taraflılık/çok taraflıık ikilemleri içerisinde ağılıklı olarak müdahaleci ve yerine göre de tek başına ya da uluslararası desteği arkasına alacak bir şekilde geliştiği görülmektedir. Bu dış politika içerisinde, uluslararası sistemdeki tüm egemen devletleri bünyesinde barındıran BM ABD'nin hegemonyasını genişletme kapsamında önemli bir araç olarak ortaya çıkmaktadır. Bu bağlamda düşünüldüğünde $A B D$ ’nin hegemonyasını genişletebilmek için $B M$ gibi küresel bir örgüte ihtiyaç duyduğunu söylemek mümkündür.

$A B D$ 'nin $B M^{\prime} y e$ olan bu gereksiniminin yanı sıra, söz konusu iki aktör arasındaki ilişkinin diğer ucunda BM'nin de $A B D$ 'ye olan bağımlılığı bulunmaktadır. Bunun iki sebebi olduğunu söylemek mümkündür. Birincisi doğrudan BM'nin organizasyon yapısından ve ABD'nin bu yapı içerisinde sahip olduğu rolden kaynaklanmaktadır. Bilindiği üzere $A B D, B M$ Sisteminin ana yürütme organı olarak görülen Güvenlik Konseyi'nin daimi üyesidir ve bu sıfatla BM'nin alması gereken önemli kararlarda veto yetkisi bulunmaktadır. Dolayısıyla BM'nin, Şartı gereği aktif rol oynaması gereken durumlar karşısında diğer daimi üyeler gibi $A B D^{\prime}$ nin onayı olmaksızın hareket etmesi mümkün değildir. Dahası sahip olduğu süper güç statüsü ve kuruluşundan bu yana ABD'nin BM üzerindeki etkisi BM'nin uluslararası sorunlarla mücadelesinde ABD'nin liderlik etmesini gerekli kılmakta, ABD’nin çekimser kaldığı sorunlar karşısında ise örgütün kimi zaman çok yavaş hareket etmesine, kimi zamansa hiç hareket edememesine neden olmaktadır. Soğuk Savaş sonrası dönemin ilk yılla- 
rında Ruanda, bugün ise Suriye krizlerinde BM'nin sessiz kalması ABD desteği olmadan örgütün nasıl etkisini yitirdiğine yönelik ilk akla gelen örnekler arasındadır.

BM'nin ABD'ye olan bağımlılı̆ının bir diğer boyutu ise ABD’nin sahip olduğu askeri ve ekonomik güçten kaynaklanmaktadır. Bilindiği üzere BM'nin en önemli misyonu uluslararası barışı ve güvenliği korumaktır (BM Şartı, Madde 1, 1945). Bu kapsamda kuruluş aşamasında BM Şartında da değinildiği gibi BM komutası altında bir silahlı gücün kurulması ön görülmüş, fakat bu hiçbir zaman gerçekleşmemiştir (BM Şartı, Madde 47, 1945). Bundan dolayı BM en temel vazifesi olan uluslararası barışı ve güvenliği sağlayabilmesi için devletlerin askeri gücüne ihtiyaç duymaktadır. Bu ihtiyaç, Somali örneğinde olduğu gibi kimi zaman devletlerin askeri personellerini doğrudan BM komutası altına vermesi, kimi zaman da Körfez Savaşında olduğu gibi ülkelerin direkt olarak bu görevi BM adına gerçekleştirmesi yoluyla giderilmektedir. Bu kapsamda ABD'nin askeri gücü BM'nin gerçekleştirmek istediği askeri operasyonlar için büyük bir öneme sahiptir. Zira 1990'lar boyunca BM çatısı altında yapılan bütün askeri operasyonlarda ABD başı çekmiştir (Malone 2003, s.77).

ABD’nin BM için vazgeçilmez olan maddi katkısının bir diğer boyutunu ise ABD'nin BM bütçesine olan desteği oluşturmaktadır. BM bütçesi tamamen üyelerinin sağladığı finansal desteklerden oluşturulmaktadır. Söz konusu destekler genel olarak üyelerin ödemek zorunda olduğu meblağlar ve yine üyelerden gelen gönüllü bağışlardan ibarettir. BM Genel Kurulu iki senede bir olmak üzere, BM'nin tahmini bütçesini hazırlamakta ve üyelerin bu bütçeye katkısını karara bağlamaktadır. Üyelerin bütçeye ne kadar katkı yapacağı ise üyelerin ekonomik koşulları göz önüne alınarak belirlenmektedir. Buradaki en önemli kısıt üyelerin bütçe katkı oranlarına ilişkin alt ve üst limitlerdir. Buna göre hiçbir devlet BM bütçesinin \%0.1'nin altında yada \%22'sinin üzerinde katkı yapamayacaktır.

Genel Sekreterlik tarafından hazırlanmış olan bir rapora göre ABD’nin 2013/14 ve 15 senelerine ait zorunlu ve gönüllü yardımları ortalama 9 milyar dolar seviyesinde gerçekleşmiştir. Aşağıdaki tabloda da görüldüğü gibi ABD’nin yıllık katkısı en yakın takipçisi Büyük Britanya'nın katkısının neredeyse 3 katına tekabül etmektedir (Secretary-General'sNote2016).

Tablo 1. BM Olağan Bütçesine ve Fonlarına En Fazla Zorunlu ve Gönüllü Katılım Yapan Ülkeler (ABD Doları)

\begin{tabular}{|c|c|c|c|c|}
\hline & Ortalama & 2013 & 2014 & 2015 \\
\hline$A B D$ & $9,330,352,554$ & 7.682 .202 .639 & 10.077 .846 .897 & 10.231 .008 .126 \\
\hline Birleşik Krallık* & $3,291,835,507$ & 3.283 .877 .268 & 2.962 .521 .260 & 3.629.107.993 \\
\hline Japonya & $2,932,649,203$ & 3.022 .415 .482 & 2.802 .092 .478 & 2.973 .439 .648 \\
\hline Almanya & $2,151,496,024$ & 1.895 .551 .439 & 2.229.176.709 & 2.329.759.924 \\
\hline Kanada & $1,445,692,215$ & 1.593 .133 .334 & 1.376.143.531 & 1.367.799.781 \\
\hline
\end{tabular}


Tamer KAŞIKÇI

\begin{tabular}{lcccc}
\hline İsveç & $1,341,839442$ & 1.353 .844 .168 & 1.284 .435 .728 & 1.387 .238 .429 \\
Norveç & $1,247,877,736$ & 1.363 .474 .429 & 1.262 .620 .055 & 1.117 .538 .724 \\
Fransa & $1,119,371,745$ & 1.054 .305 .634 & 1.123 .040 .775 & 1.180 .768 .825 \\
Hollanda & $1,101,040,689$ & 1.075 .478 .147 & 1.080 .715 .246 & 1.146 .928 .673 \\
Brezilya & $898,521,310$ & 655.009 .832 & 1.170 .457 .618 & 870.096 .479 \\
\hline
\end{tabular}

Kaynak: (Secretary-General'sNote: 2016)

BM'nin olağan bütçesine (regularbudget) yapılacak olan devlet katkılarının yıllara göre dağılmına bakıldığında sadece ABD’nin bütçenin \%22'sini karşılayabildiği görülmektedir. Yapılan değerlendirmelerde ABD'nin ekonomik koşulları nedeniyle bu rakamdan daha fazlasını karşılaması gerekirken, daha önce alınan üst limit kararı gereği ABD'nin yapması gereken destek bu rakamda kalmıştır (The US andthe UN in 2016, 2017). Diğer devletler ile karşılaştıııldığında, 2016-2018 bütçe değerlendirmesinde ABD'nin ardından ikinci sırada gelen Japonya'nın toplam bütçe içerisindeki payının \%9.6, üçüncü sıradaki Çin'in ise \%7.9 olduğu görülmektedir (BM Genel Kurul Kararı, A/Res/70/245, 2015).

Şekil 1. Barış Koruma Operasyonları En Fazla Destek Veren Ülkeler (2016)

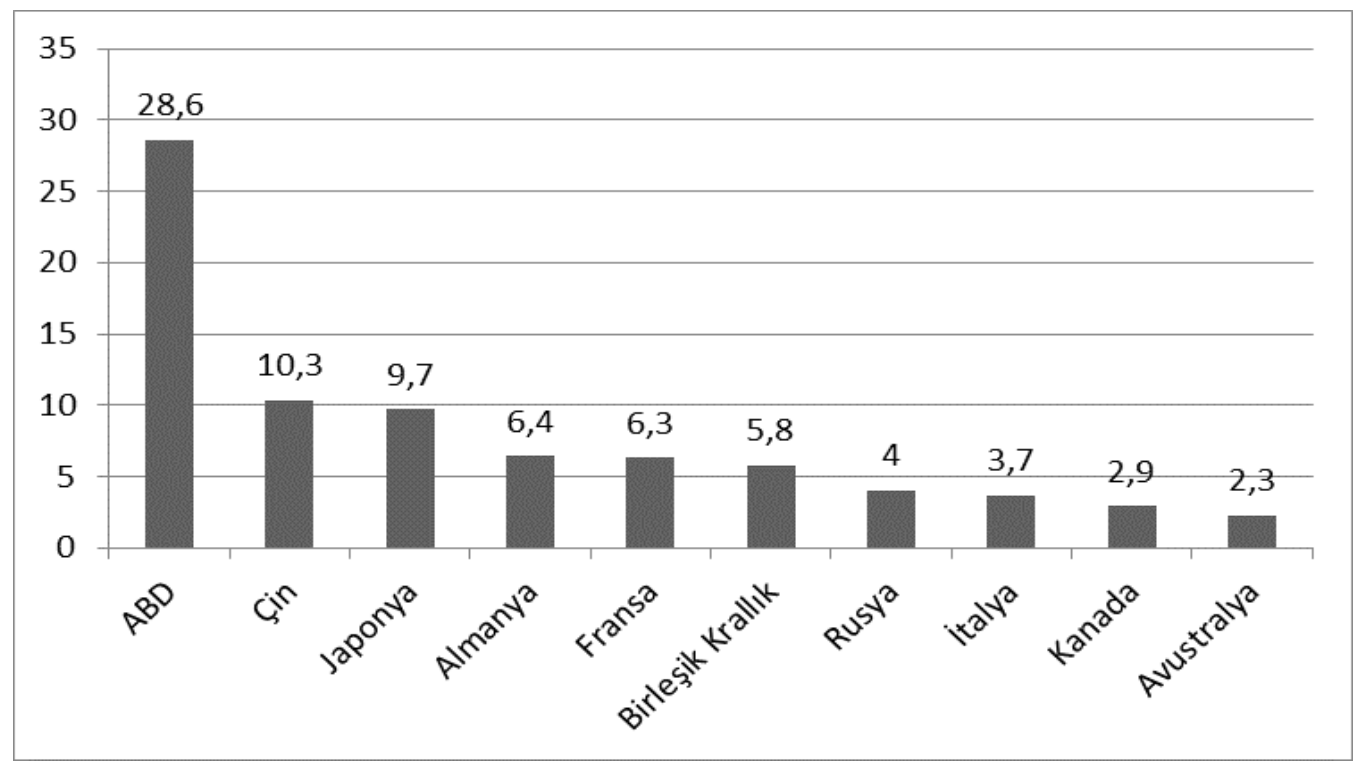

Kaynak: (Top 10 Financial ContributorsTo UN Peacekeeping Budget 2016). 
ABD’nin BM'ye olan finansal katkısının bir diğer önemli boyutunu da BM’nin uluslararası barışı koruma bağlamında kilit bir rol oynayan barış koruma operasyonlarına yaptığı destek teşkil etmektedir. Barış koruma operasyonlarının bütçesi de iki yıllık olarak oluşturulmakta ve devletlerin bu bütçeye katkısı yine ekonomik koşullarına bağlı olarak değerlendirilmektedir. ABD burada da en çok katkı yapan ülkeler içerisinde başı çekmektedir. Yukarıdaki grafikte de görüldüğü gibi ABD 2016 yılı içerisinde barış koruma operasyonlarının toplam bütçesinin \%28'ini tek başına karşılamaktadır. Bu kategoride ABD'nin en yakın takipçisi toplam bütçenin \%10'unu karşılayan Çin olmuştur. (Top 10 Financial ContributorsTo UN Peacekeeping Budget 2016).

Yukarıda dile getirilen verilerin açık bir şekilde ortaya koymuş olduğu gibi, BM’nin hem örgüt ihtiyaçlarını hem de üstlendiği operasyonların maliyetini karşılamada ABD’nin diğer ülkeler karşısında önemli bir ağırlığı bulunmaktadır. Bu durum, varlığının ekonomik boyutunu zaten devletlere borçlu olan BM'nin, ABD'ye olan bağımlılığını daha da derinleştirmekte, örgütün ABD ile ilişkilerinin diğer devletlerle ilişkileri ile karşılaştırıldığında ayrı bir kapsamda değerlendirilmesini gerekli kılmaktadır.

\section{BM’nin Uluslararası Sistemdeki Normatif Etkisi}

Bir yandan $A B D$ kendi istediği gibi bir dünya düzeni oluşturma konusunda BM'ye ihtiyaç duyarken diğer yandan BM de varlığını sürdürebilmek için ABD’nin desteğine muhtaçtır. Bu karşılıklı bağımlıık ilişkisi bu iki aktör arasındaki ilişkinin bir boyutunu oluşturmaktadır. $B M$ ve $A B D$ arasındaki ilişkinin bir başka boyutu da BM'nin ABD dış politikası üzerindeki etkisidir.

ABD’nin BM'nin kurulmasında ve hayatta kalmasında en önemli paya sahip ülke olması ABD$B M$ ilişkisinin tek taraflı bir ilişki olmasını gerektirmemektedir. Her aktör-yapı ilişkisinde olduğu gibi (Arts, 2000, s.524-525) ABD-BM ilişkisi de iki taraflı bir ilişkiye dayanmaktadır. BM’nin ABD’nin dış politikası üzerindeki etkisi, BM’nin bugünkü uluslararası sistemin normatif boyutunun şekillenmesinde oynadığı merkezi rolden kaynaklanmaktadır. Bu argümanı açıklayabilmek için öncelikle uluslararası yapının normatif boyutunu ve BM'nin bu boyutun oluşumunda oynadığı rolü analiz etmek gerekmektedir.

Uluslararası sistemin yapısına ilişkin analizlerin öncülerinden olan Kenneth Waltz söz konusu yapıyı sadece devletlerin kapasite dağılımları neticesinde ortaya çıkan bir unsur olarak tanımlarken (Waltz 1979, s.97-99), Waltz'un bu yaklaşımını indirgemeci bulan yazarlar uluslararası yapıyı materyal boyut ve normatif boyut olmak üzere iki boyutlu bir unsur olarak tanımlamaktadır (Dessler 1989). Materyal boyut, sistemi oluşturan aktörlerin materyal kapasitelerinden meydana gelirken, normatif boyut aktörlerin iradi eylemleri neticesinde oluşturdukları kuralları ve normları içermektedir (Dessler 1989, s. 459, Arend 1999, s.127). Söz konusu kurallar ve normlar aktörlerin birbirleri ile ilişkilerinin mümkün olması için gerekli zemini sağlarken diğer yandan da yine aktörlerin davranışlarının sınırlarını belirlemektedir.

Uluslararası sistemin normatif boyutu genel olarak sistemin ana aktörleri olan devletlerin birbirleri ile yaptıkları anlaşmalardan ve uluslararası hukukun benzer kaynaklarından meydana gelmektedir (Dessler 1989, s.461-463). BM hem kurulduğu dönemde söz konusu normatif yapının 
temel ilkelerini kurucu sözleşmesi (BM Şartı) içerisinde yasal bir zemine oturtarak, hem de sahip olduğu norm üretim mekanizmaları (Genel Kurul kararları, Güvenlik Konseyi kararları, BM bünyesinde yer alan uzman kuruluşların norm üretim süreçleri vb.) aracılı̆ı̀la uluslararası toplumun karşılaşmış olduğu yeni sorun alanlarına ilişkin normlar üreterek bu normatif yapının geliştirilmesinde önemli bir rol oynamaktadır (Young 1968, s.902). Dahası, yine BM sahip olduğu sosyalizasyon mekanizmaları (ülke raporları, yaptırımlar, askeri operasyonlar vb.) ile söz konusu normatif yapının korunmasında ve uluslararası sistemin aktörleri tarafından benimsenmesinde de kilit bir role sahiptir.

BM'nin gerek Şartı gerekse de yeni oluşturduğu normlar aracılığıyla çizilmiş olan bu normatif çerçeve, $A B D$ de dahil olmak üzere tüm devletleri içine almakta ve tüm üyelerin bu normatif çerçeve içerisinde hareket etmesini zorunlu kılmaktadır. Daha somut bir dille ifade etmek gerekirse, tek süper güç olmasına rağmen ABD, BM'nin tek taraflı kuvvet kullanımı, iç işlerine karışmama, insan hakları ihlalleri ve benzeri konularda bugünkü uluslararası hukukun temeli haline gelmiş yasak ve ilkeleri çerçevesinde hareket etmek durumundadır. Bu anlamda BM'nin tek süper güç olan ABD’nin hareketlerini kıııtladığı ve istediği her şeyi yapmasını engellediği ileri sürülebilir. Bir başka deyişle ABD BM'yi destekleyerek kendini de bu çerçevenin içerisine sokmakta ve sınılandırmaktadir (Finnemore 2009, s.71-72).

Çağdaş uluslararası sistemin devletler arası ilişkileri düzenleyen ve sınılayan normatif bir boyutunun olduğu ve BM'nin bu normatif boyutun oluşmasında, gelişmesinde ve korunmasında merkezi bir rol oynadığı aşikardır. Ancak bu noktada, sahip olduğu askeri ve ekonomik güç ile sistem içerisinde özel bir yeri bulunan ABD’nin kendini bu normatif çerçeve içerisinde sınırlamasının nedenlerini açıklamak gerekmektedir. Bunun iki önemli sebebi bulunmaktadır. Ilk olarak, her ne kadar ABD bugüne kadar görülmemiş muazzam bir askeri kapasiteye sahip olsa da bu materyal güç dünyanın geri kalanının bu güce boyun eğmesini sağlamakta yetersizdir. Zira hegemonyanın diğer devletler tarafından kabulü, bu devletlerin rızasına bağlıdır. Daha önce de değinildiği gibi ABD hegemonyasını dünyaya yaymak için sadece materyal gücünü değil, bunun yanı sıra devletlerin rızasını kazanacak bir takım değerlere ve kurumlara dayanmak durumundadır (Cronin 2001, s.122). $A B D$ bu yüzden insan hakları ve demokrasi gibi değerleri el üstünde tutarak eylemlerini dünyayı daha yaşanabilir kılacak olan bu değerleri geliştirme amacına dayandırmaktadır. Aynı şekilde ABD, diğer devletlere uluslararası barış ve güvenliği ne derece önemsediğini göstermek adına BM'yi desteklemektedir. Bir anlamda ABD'nin BM'ye olan bu desteği ABD'nin sadece kendi çıkarını düşünerek hareket eden bir devlet olmadığını göstermeye ve diğer devletler gözündeki imajını geliştirmeye yönelik bir politikadır (Finnemore 2009, s.74-75).

ABD’nin bu normatif çerçeve içerisinde kendini sınırlandırmasının bir başka sebebi de bu yapının süper gücün karşıındaki diğer devletleri de normatif bir çerçeve içerisinde sınırlamasıdır. BM üyesi tüm devletler kendilerini BM Şartı ile sınılandırmış bulunmaktadır. Bu Şartın ağırıkı olarak ABD tarafından şekillendirildiği göz önünde tutulduğunda, bu durum, bir anlamda ABD’nin diğer devletleri herhangi bir zorlama gayreti içerisine girmeden kendi istediği yönde sınırlandırdığı 
anlamına gelmektedir (Ikenberry 2003, s. 53-54). Bu sebepten ötürü ABD BM Şartı ile sınırlandırımayı kabul etmektedir.

Ancak her ne kadar ABD kendini BM'nin merkezinde olduğu bu normatif yapı ile sınırlandırsa da zaman zaman ABD’nin çıkarları bu sözleşmenin dışına çıkmasına sebep olmaktadır. Burada yaşanan paradoks bu normatif yapı oluşturulurken ön görülen ilke ve değerlerin uzun vadede Amerikan çıkarları ile çatışmasından kaynaklanmaktadır. ABD bu paradoksu aşmak için zaman zaman hipokrasiye (riyakarlık) ${ }^{1}$ başvurmaktadır. $A B D$ yönetimleri her platformda söz konusu normatif yapının temel ilkelerini savunurken, çıkarlarının gerektirdiği durumlarda bu ilkeleri göz ardı etmektedir. Hegemonyasını yaygınlaştırmak ve diğer devletleri belirli bir normatif çerçevenin içerisinde hareket etmeye zorlamak için BM sistemi içerisinde bir anlamda kendini de sınırlamaya razı olan ABD’nin Soğuk Savaş sonrası BM ile olan ilişkileri, zaman zaman bu sınırlama yüzünden gerilmiş ve $A B D$ çıkarlarını korumak için bu normatif sınırın dışına çıkmaktan kaçınmamıştır.

Bu duruma yönelik en iyi örnek, yukarıda da kısaca değinilen 11 Eylül sonrası terörle savaş doktrini kapsamında yapılan operasyonlardır. 11 Eylül saldırıları, ABD’nin tehdit algılamalarının yanı sıra uluslararası düzen konusundaki düşüncelerinde de ciddi bir değişim yaratmıştır. Bu tarihe kadar BM Şartı temelinde gelişen uluslararası hukuksal çerçeveyi mümkün olduğunca destekleyen $A B D$, bu tarihten sonra ilan ettiği terörle savaş doktrini kapsamında düşmanını yok etmek adına hiçbir sınırlamayı kabul etmemektedir. Bu kapsamda yapılan Afganistan operasyonu uluslararası toplum tarafından meşru olarak kabul edilmişse de Irak operasyonu herhangi bir hukuki dayanağa sahip değildir. Bir başka deyişle ABD Irak operasyonunda BM Şartının iki temel prensibini- kuvvet kullanma yasağı ve iç işlerine karışmama ilkesi- yok saymıştır. Irak operasyonu ABD’nin çıkarları söz konusu olduğunda uluslararası normatif yapının en temel prensiplerini dahi çiğnemekten çekinmediğini açıkça göstermektedir (Ikenberry2002, s.5-6).

\section{Sonuç}

Soğuk Savaşın sona ermesiyle birlikte uluslararası sistemde tek süper güç olarak kalan ABD’nin, "uluslararası barışı korumak" misyonu ile mevcut küresel nitelikli uluslararası örgütler arasında ayrı bir yere sahip olan BM ile ilişkisi uluslararası ilişkiler disiplini açısından açıklanması gereken önemli konulardan bir tanesidir. Söz konusu dönemde ABD-BM ilişkisinin öncelikle karşılıklı bir faydacılık zeminine dayandığı görülmektedir. Soğuk Savaş sonrası dönemde dış politikasını, hegemonyasını korumak ve yaygınlaştırmak amacıyla dünyanın hemen hemen her yerine müdahale etme stratejisi üzerine kuran ABD yönetimleri, söz konusu stratejiyi uygulayabilmek için zaman zaman BM gibi uluslararası örgütlerin yardımına başvurmuştur. Bu bağlamda ABD dış politikaSı açısından, sistemdeki hemen hemen tüm uluslararası aktörleri bünyesinde toplamış olan BM vazgeçilmesi zor bir unsur olarak görülmektedir.

\footnotetext{
${ }^{1}$ Hipokrasi kelime anlamı ile, bir değeri savunurken onun zıttında eylemde bulunmaktır.
} 
Diğer yandan BM de hem varlığını sürdürmek hem de dünyanın dört bir yanında üstlenmiş olduğu operasyon ve projeleri gerçekleştirebilmek için $A B D$ gibi dünyanın en önemli askeri ve ekonomik gücünün özellikle finansal desteğine intiyaç duymuştur. Bu bağlamda BM de sistem içerisindeki varlığını sürdürebilmek için giderlerinin büyük bir kısmını karşılayan ABD’ye muhtaç olduğu görülmektedir. Bu durum iki aktör arasında karşılıklı bir fayda ilişkisi yaratmaktadır.

Bunun yanı sıra, BM'nin merkezinde yer aldığı uluslararası sistemin normatif boyutu, sistem içerisindeki diğer tüm aktörlerin olduğu gibi ABD’nin de politikalarını hem mümkün kılmakta hem de sınırlandırmaktadır. Bu bağlamda her ne kadar ABD sistem içerisindeki en güçlü aktörlerden birisi olsa da, BM'nin oluşumunda en etkili aktör olduğu sistemin normatif boyutu içerisinde hareket etmek zorunda kalmakta, 2003'teki Irak operasyonunda olduğu gibi bu normatif boyutun dışına çıktığında önemli bir meşruiyet krizi ile karşılaşmaktadır. Görüldüğü üzere böylesi meydan okumalar uzun vadede ABD’nin uluslararası sistemdeki etkisini zayıflatmaktadır. Tüm bunlar göz önüne alındığında ABD-BM ilişkisinin tek taraflı değil, iki tarafı bir ilişki olduğunu ileri sürmek mümkündür. Bununla birlikte BM’nin ABD’nin dış politikasını tamamen yönlendirebildiğini iddia etmek de ütopik bir yaklaşım olacaktır.

\section{Kaynaklar}

Aaronson, Mike. (2014).Interventionism in US Foreign Policy From Bush to Obama. Obama's Foreign Policy: Ending the War on Terror. Ed. Michelle Bentley ve Jack Holland. Oxon: Routledge. ss.124-138.

Arend, Anthony Clark (1999). Legal Rules and International Society. Oxford: Oxford University Press.

Arts, Bas (2000).Regimes, Non-State Actors and the State System: A 'Structurational' Regime Model. European Journal of International Relations. Vol 6(4).ss.515-544.

BM Şartı (1945). http://uhdigm.adalet.gov.tr/sozlesmeler/coktaraflisoz/bm/bm 01.pdf, (Erişim Tarihi: 12 Aralık 2017).

Bosco, David L.(2009).Five to Rule Them All: The UN Security Council and The Making of the Modern World. Oxford: Oxford University Press.

Bush, George (1991).Operation Desert Storm Launched. Address to the Nation from the White House.

Ocak.http://dosfan.lib.uic.edu/ERC/briefing/dispatch/1991/html/Dispatchv2no03.html, (Erişim Tarihi: 21 Aralık 2017).

Buzan, Barry ve Waever, Ole (2003).Regions and Powers. Cambridge: Cambridge University Press.

Cameron, Fraser (2005).US Foreign Policy after the Cold War: Global Hegemon or Reluctant Sheriff? Second Edition.Oxon: Routledge. 
Cronin, Bruce (2001).The Paradox of Hegemony: America's Ambiguous Relationship with The United Nations. European Journal of International Relations. Vol.7. ss.103-130.

Daalder, Ivo H. (2016).Obama's Foreign Policy: Not Every Global Problem has an American Solution. The Washington Post.https://www.washingtonpost.com/graphics/national/obamalegacy/effect-on-global-politics.html, (Erişim Tarihi: 17 Aralık 2017).

Dessler, David (1989).What's Stake in the Agent-Structure Debate? International Organization. Vol.43. No.3. ss.441-473.

Finnemore, Martha (2009). Legitimacy, Hypocrisy, and The Social Structure of Unipolarity.World Politics. 61. No 1. ss.58-85.

Haig, Alxander M.JJ. (1991).The Challenges to American Leadership. US Foreign Policy in the 1990s. Ed. Greg Schmergel. New York:Palgrave Macmillian. ss.34-46.

Herring, George C. (2008). From Colony to Superpower: US Foreign Relations since 1776. ABD: Oxford University Press.

Holland, Jack (2014).Introduction: Why is change so hard? Understanding continuity in Barack Obama's foreign policy. Obama's Foreign Policy: Ending the War on Terror. Ed. Michelle Bentley ve JackHolland, Oxon: Routledge. ss.1-16.

Howard, Lise Morje (2010).Sources of Change in the United States-United Nations Relations. Global Governance. Vol.16. No.4. ss.485-503.

Ikenberry, G. John (2003).State Power and the Institutional Bargain: America's Ambivalent Economic and Security Multilaretalism. US Hegemony and International Organizations. Ed. Rosemary Foot, S. Neil MacFarlane, ve Michael Mastanduno. Oxford: Oxford University Press. ss.49-72.

Ikenberry, G. John (2002).America's Imperial Ambition.Foreign Affairs. Vol. 81. Issue 5. ss.44-60.

Ikenberry, G. John (2000).America's Liberal Grand Strategy: Democracy and National Security in the Post-War Era.American Democracy Promotion: Impulses, Strategies and Impacts. Ed. M. Cox, G.J. Ikenberry, ve T. Inoguchi, Oxford: Oxford UniversityPress. ss103-127.

Johnstone, Ian (2004). US-UN Relations after Iraq: The End of the World (Order) As We Know It? EJIL. Vol 15. No 4.ss. 813-838.

Keskin, Funda (2005). Birleşmiş Milletler ve Türkiye. Ankara: Ekin Yayınları.

Keskin, Funda (1998).Uluslararası Hukukta Kuvvet Kullanma: Savaş, Karışma ve Birleşmiş Milletler. Ankara: Mülkiyeliler Birliği Vakfı Yayınları.

Krauthammer, Charles. (1991). The Unipolar Moment. Foreign Affairs.Vol. 70. No.1. America and the World. ss.23-33. 
Malone, David M. (2003).US-UN Relations in the Security Council in the Post Cold War Era. US Hegemony and International Organizations. Ed. Rosemary Foot, S. Neil MacFarlane, ve Michael Mastanduno. Oxford: Oxford UniversityPress. ss.73-91.

Mastanduno, Michael (2008).After Bush: A Return toMultilateralism in Us Foreign Policy. Nanzan Review American Studies. Volume 30. ss.33-46.

Ostergard, Robert L. Jr. (2006). The Failure of America's Post-Cold War Foreign Policy: From the Persian Gulf to the Gulf of Guinea. The Whitehead Journal of Diplomacy and International Relations. 7. 43. ss.43-55.

Pattison, James (2010). Humanitarian Intervention and the Responsibility to Protect: Who Should Intervene? Oxford: Oxford University Press.

Powell admits Iraq evidence mistake. 13 Nisan 2004).BBC.http://news.bbc.co.uk/2/hi/middle east/3596033.stm. (Erişim Tarihi 17 Kasım 2017).

Presenditial Directive Decision/ NSC 25.(3 Mayıs 1994).The White House.http://www.fas.org/irp/offdocs/pdd/pdd-25.pdf. (Erişim Tarihi: 22 Aralık 2017).

Puchala, David (2005).World Hegemony and the United Nations. International Studies Review. 7. ss.572-573.

Reisman, W. Michael (1999).The United States and International Institutions.Survival. 414.Winter.ss.62-80.

Scale of assessments for the apportionment of the expenses of the United Nations. 23 Aralık 2015).BM Genel Kurul Kararı. A/Res/70/245.http://undocs.org/en/A/RES/70/245. (Erişim Tarihi: 22 Aralık 2017).

Secretary-General'sNote: Top Ten Providers of Assessed Contributions to United Nations Budgets and of Voluntary Contributions to United Nations Funds. Programmes and Agencies, including the standing Peacebuilding Fund. (3 Kasım 2016). Birleşmiş Milletler. http://www.un.org/pga/71/wp-content/uploads/sites/40/2015/08/Top-ten-providers-ofassessed-contributions-to-United-Nations-budget-and-of-voluntary-contributions-to-theUnited-Nations-funds-programmes-andagencies_3-Nov.pdf. (Erişim Tarihi: 22 Aralık 2017).

Text of President Bush's 2002 State of the Union Address.(29 Ocak 2002).The Washington Post. http://www.washingtonpost.com/wp-srv/onpolitics/transcripts/sou012902.htm. (Erişim Tarihi: 15 Aralık 2017).

The US and the UN in 2016: Congressional Briefing Book. Better World Campaign.https://betterworldcampaign.org/wp-content/uploads/2016/02/BWC-BriefingBook-2016.pdf, (Erişim Tarihi: 15 Aralık 2017). 
Top 10 Financial ContributorsTo UN Peacekeeping Budget August 2016. (1 Eylül 2016). Peace Operations Review.http://peaceoperationsreview.org/infographic/top-10-financialcontributors-to-un-peacekeeping-budget-aug-2016/. (Erişim Tarihi: 24 Aralık 2017).

Transcript of President Bush's address to a joint session of Congress on Thursday night, September 20, 2001. (21 Eylül 2001).BBC.http://edition.cnn.com/2001/US/09/20/gen.bush.transcript/. (Erişim Tarihi: 24 Aralık 2017).

Volger, Helmut (2010).History of the Foundation of the UN.A Concise Encyclopedia of the United Nations. Ed. Helmut Volger. Second Revised Edition. Leiden-Boston: Martinus Nijhoff Publishers.ss.216-230.

Waltz, Kenneth (1979). Theory of International Politics. ABD: Addison-Wesley Publishing Company.

Wolfgang, Ben (2017).In U.N. Address, Trump Replaces Obama's Soft Talk with Big Stick.The Washington Post. 19 Eylül.https://www.washingtontimes.com/news/2017/sep/19/donaldtrump-ends-barack-obamas-un-policy/. (Erişim Tarihi: 16 Aralık 2017).

Young, Oran R. (1968).The United Nations and the International System. International Organization. Vol.22. No.4. (Güz). ss.902-922. o.4. (Güz). ss.902-922. 